\title{
Ecological Problems of Middle Volga in the Second Half of the XXth Century: Historical and Ecological Analysis of Leading Industrial Regions Development
}

\author{
Aidar M. Kalimullin ${ }^{1}$ \\ ${ }^{1}$ Kazan (Volga region) Federal University, Kazan, Russia \\ Correspondence: Aidar M. Kalimullin, Kazan (Volga region) Federal University, Kremlyovskaya Street 18, \\ Kazan 420008, Russia.
}

Received: October 24, 2014

Accepted: December 3, 2014 Online Published: December 18, 2014

doi:10.5539/res.v7n1p86

URL: http://dx.doi.org/10.5539/res.v7n1p86

\begin{abstract}
The present article is aimed to identify origins and evolution of environmental problems characteristic for Middle Volga Region in the second half of the XXth century. The approach applied for the research allows to analyze the industrial growth of the country from a totally new level, to observe the course, character and peculiarities of its impact on the ecological degradation that determines the critical condition of environment at the present stage. The article reveals the results of historical and ecological analysis conducted by Russian and foreign researchers on issues of a human and environment interaction; they make it possible to designate for Russia such perspective scientific guidelines of studying contradictions in the system "human nature" as: origins and evolution of industrial pollution, ecological problems of urbanized territories, dynamics of natural resources exhaustion, water utilization history. The materials of this article may facilitate the efficient usage of economic, technological, moral and organizational methods aimed to impact the developing economic system, its highest ecologization.
\end{abstract}

Keywords: ecological history, historical and ecological analysis, evolution of industrial pollution, environmental problems, Samara region, the Republic of Tatarstan

\section{Introduction}

The historical approach to the characteristic of the major industrial pollutants in a specific region has brought out their close interrelation with the process of the previous economic development of the country when for a long period natural resources were used according to the postulate of their infinity and invariance. The development of the USSR strong industrial base was accompanied with intensive forest devastation, decrease in natural soil fertility, large-scale pollution of rivers and other negative processes that resulted in a strong interconnected triad: heavy industry - ecology - population health. Industrial progress culminated in a huge volume of pollution in the biosphere which negatively influenced soils, vegetation, reservoirs, atmosphere and a human.

The guideline of the historical and ecological research allowed to determine the following regularities of environmental pollution caused by industrial production:

- the impact of industrial production on the degree of surrounding environment ecological safety (atmospheric air, water objects, subsoil, land, vegetable and animal resources condition) is complicated and equivocal. The most indicative example of environment pollution is atmospheric air, where the emission of ingredients characteristic to those types of productions which are most developed in the specific region or city of Russia are determining;

- the technogenic impact of industrial enterprises and objects of municipal economy perniciously affects the quality condition of water resources. The areas of contaminated water are increasing due to the fact that new local sources of pollution are appearing, but what aggravates the situation is the fact that in many cases different toxic substances begin to mix up and are getting intensified. By estimates of Russian water management and nature protection bodies, a significant amount of polluting substances from enterprises of ferrous and nonferrous metallurgy, chemical, petrochemical, coal, machine-building, pulp and paper industry, objects of power and housing and communal services get into surface water. Water sources in a number of regions of Middle and Lower Volga, South Ural are the most polluted; 
- the development of industry and transport networks inevitably leads to the growth of anthropogenic burden upon land resources. Along with noticeable changes in the lithosphere as the result of mining by an open way, the pollution and littering of lands because of town-planning and other technogenic activity have also become significant ecological problems. Among substances polluting soil there prevail radionuclides, oil and oil products, heavy metals, dioxin and dioxin-like toxicants, etc.;

- among technogenic burdens the environment experiences and that impact the condition of land resources, the problem of production wastes and consumption deserves special attention. The problem of solid household waste (SHW) accumulation and removal is particularly urgent in large cities and megalopolises with the population over 1 million people.

The historical and ecological analysis of the most nature destroying industries of Middle Volga region (oil, energy, chemical, petrochemical, machine-building) has revealed specifics of some productions impact on the environment; they are caused by the emission of some impurities the structure of which can comprise dozens of thousands of substances. It allowed to confirm the conclusion that environmental problems are interconnected with various aspects of productive forces placement, and basically with territorial unevenness and resource attachment to the placement. This and insufficient work of treatment facilities result in steadily high environmental pollution at the present stage. In this regard the most important condition aimed at the solution of many local nature protection problems that, in its essence, make a general global environmental problem, is the elaboration of such a long-term strategy of industrial centers (regions) development which would mean its high-quality change, including transformation into a closed complex. The world practice testifies to the necessity of industrial units ecological modernization of various productions that provide maximum possible consecutive, irrevocable production cycles the main task of which consists in the reduction of harmful emissions in the environment.

Due to the integrity of the problem and deep inner interconnection of all the components and phenomena, the solution of this problem should be undertaken by representatives of different scientific spheres, the key role should be given to history science (Kalimullin, 2014; Tvedt, 2010). Its major task concerning the study of ecological issues is to seek new paradigms of civilizational development on the basis of the previous experience analysis the human has obtained while interacting with nature; this will undoubtedly enrich human's ideas about possible ecological-economic contradictions (Kalimullin, 2006; Al-Nawafleh, 2005; Walliss, 2012; Wikan, 2012).

\section{Methodological Framework}

Chronological framework of this research is limited to the period of the 1950-1990s; it is characterized as one of the most difficult and inconsistent periods in national history. The second half of the XXth century was rich in important events of social and economic life; there were numerous attempts of economic reforms within the existing system that had direct impact on the formation of environmental problems.

A substantial variety of the considered period allows to confirm the typicality of nature protection problems at global, national, and regional levels; these problems were caused by a large-scale program of industrial construction when new industrial and fuel and energy centers were established at the expense of natural resources wastefulness, and then, decades after, they turned into regions of ecological disasters. The second half of the XXth century is regarded as the time of humankind's ecological consciousness development as the threat to its existence was connected not only with a nuclear apocalypse, but also with a possible ecological disaster due to destructive anthropogenic activity.

Territorial borders of the research cover the two most industrially developed regions of Middle Volga-the Republic of Tatarstan and Samara region, their economic indicators allowed them to enter the number of leading subjects of the Russian Federation at the turn of the XX-XXIth centuries, and to be ranked as a small group coming nearer to a post-industrial level according to some indicators. Total volumes of industrial production of the considered regions make respectively about $8 \%$ of all-Russian and more than $35 \%$ of the integrated indicators of 14 subjects of the Volga federal district.

The history of industrial complexes formation and development in the Republic of Tatarstan and Samara region in the second half of the XXth century in the structure of which mechanical engineering, oil production, power, chemistry and petro-chemistry have a dominating position, generally corresponds to the most important tendencies of the USSR economic development during the post-war period; that gives a chance to reveal regularities of ecological situation aggravation not only in a specific region, but also in the country as a whole. The experience of similar regions development is important due to the fact that it proves the typicality of reasons that cause an intense ecological situation in industrially developed regions of Russia, which historically 
developed due to the exclusive concentration of group "A" industrial enterprises that were established without scientifically reasonable calculations of urbanized territory ecological capacity, without regarding their climatic, economic, and demographic features.

\section{Results}

The process of leading industrial centers development in the second half of the XXth century has rather complex and inconsistent character. These decades take an important place in the economic development of the considered regions. Statistical comparisons testify that for a long time the rates of their industrial growth significantly advanced all-union ones, especially in the period of the VIII-X Five-Year-Plans (1966-1980). Summary indicators of industrial production growth in Samara region and the Republic of Tatarstan for the $1960-1990$ s are significant; they are $703 \%$ and $671 \%$ respectively.

Prerequisites of huge industrial breakthrough during the considered period were established in the years of Soviet industrialization, and they were strengthened by considerable structural changes during the military period. In 1941-1945 in the Tatar Republic and Kuibyshev area there appeared a number of new industrial branches some of which were based on more than 150 evacuated enterprises that determined the main directions of further industrial development in Middle Volga region. Fast repurpose and adaptation of industrial production to the conditions of the peace time accompanied with restoration, reconstruction of old and construction of new industrial enterprises become the most important task of post-war economy recovery in the region.

Developed industrial basis with the subsequent attraction of large financial, material, human resources allowed to create leading industrial centers of the Russian Federation in the second half of the XXth century. The powerful production potential focused originally on the extraction and processing of natural resources promoted the development and expansion of other industries. At the same time, during practical implementation of economic plans at the specified period there were brought out some disadvantages of an economic mechanism operating at that time, the inefficiency of the super-centralized economy. Objective economic and technical evaluation did not dominate; departmental dissociation, failures in the implementation of planned decisions involved their non-performance and falsification.

In the 1950-1980s the main specialization of the Tatar Autonomous Soviet Socialist Republic and Kuibyshev area was defined: the first became a machine-building and oil-extracting region with the accompanying development of petro-chemistry, power, and to a lesser extent other branches; the second developed into a versatile military-industrial region with defence, chemical, aviation industries, mechanical engineering and oil production.

The comparative analysis of Middle Volga leading industrial sectors development allows to assume that natural minerals (oil and gas) and the subsequent formation of oil and gas industries determined the development of petro-chemistry and chemistry, and also indirectly stimulated the growth of machine-building, power and some other branches. Large capital investments, involvement of people and equipment from other regions of the country made it possible to build a significant industrial complex in the 1950-1960s. Labor collectives, economic bodies had to solve challenging scientific, technical, organizational, and administrative tasks in specific conditions. Many facilities realized pilot projects where new equipment and technology, new approaches to work arrangement were tested and introduced.

The intention of the USSR ministries and departments to concentrate industry on a certain territory resulted in the formation of several industrial centers in Middle Volga industrially developed regions in the second half of the XXth century. So, by the 1990s there had appeared Nizhnekamsk territorial and production complex, Kazan-Zelenodolsky, and Almetyevsk-Bugulma industrial units on the territory of Tatarstan; Samara, Tolyatti and Syzran industrial units had grown in Samara region. The industrial structure of Middle Volga industrially developed regions generally corresponded to the national economy; it was characterized by the dominance of heavy industry, super-developed defense industry, insignificant share of light industry.

Main economic indicators assessment of the considered regions allowed to conclude that in difficult conditions that Russian economy experienced in the 1990s the industrial sector of the Republic of Tatarstan and Samara region kept their potential, their opportunities for growth. Their power systems are one of the largest in the country, regions are still among leaders of oil production in the Russian Federation, their share in chemical and petrochemical production is considerable that along with powerful scientific, technical and personnel potential, convenient geographical position creates conditions for further stable economic development.

Materials of central and regional archives reveal the nature destroying character of Soviet economic strategy that implied the left-over principle in planning and implementation of nature protection actions. The main indicators 
of environmental management planning were the volumes of capital investments in conservation, launched treatment capacities etc. All actions were, as a rule, carried out as a part of construction projects where there were no indicators reflecting final social and economic results of nature protection actions. It, in turn, did not allow to estimate the ecologic-economic efficiency of expenses to the full extent. Environmental protection was considered as an additional expense of the society which it had to bear in connection with the productive forces development that, naturally, did not facilitate environmental management optimization and ecological situation improvement.

The increased attention of the state to nature protection problems since the 1960s reflected in the adoption of legal acts, various governmental and party decisions did not lead to cardinal changes of operating regulation system and thus caused notorious expansion of ecological crisis. The formalized character of adopted acts initially made their content, they were not backed up by the effective mechanism of their implementation the core of which should form economic principles of environmental management.

The intense ecological situation which had developed by the end of the century in many largest cities and industrially developed regions of Russia became its natural result. The Republic of Tatarstan and Samara region are the largest pollutants of the Volga pool. The environmental pollution within these areas exceeds average values across the Russian Federation by 3-5 times.

Ecological problems of Middle Volga were caused, first of all, by a high concentration of oil-extracting, oil-processing and petrochemical enterprises which turned into the largest producers of some types of products. The availability of industrial giants that mainly grew in post-war years resulted in gradual transformation of Tatarstan and Samara region into the center of urgent ecological situation that is mostly obvious in such industrial centers as Samara, Tolyatti, Syzran, Kazan, Nizhnekamsk, and other cities.

\section{Discussions}

Scientific publications, a number of special works aimed at studying tendencies of technogenic impact on the environment developed within the frames of ecological history made the foundation for foreign researches characteristic.

Origin and evolution of environmental problems on urbanized territories attracted a great interest of foreign researchers: historical roots of such phenomena as air pollution, water consumption, and sewer systems development, waste collection and recycle, health care issues, dam, reservoirs, roads, transportation construction consequences were studied by Te Brake (1975), Gugliotta (2000), Stradling and Thorsheim (1999); Hipkins and Watts (1996), environment damage caused by construction of dams and channels, by destruction of rivers, violation of underground waters structure, erosion of coastlines, development of irrigational systems, construction of hydroelectric power stations were considered by Cook (1999), Paavola (2002), Schneider (1996), Pisani (2000), Velayutham (2001) and White (2000).

From the point of view of oil-extracting regions development, the historical works that show various aspects of water use in this branch and that allow to reveal and explain long-term consequences of human's various invasions in the lithosphere resulted in unpredictable processes - earthquakes, terrestrial failures, etc. are very important (Black, 1998; Santiago, 1998; Quam-Wickham, 1998).

Among less developed guidelines of historical and ecological researches there should be singled out the works that reveal in the context of their impact on nature the consequences of new chemical production (aniline, plastic, pesticides, etc.) introduced into mass production in the XXth century (Meikle, 1997; Travis, 1997), development and expansion of automobile production industry (McCarthy, 2001), process of industrial impact on land resources (Cumbler, 2000; LeCain, 2000), changes of economic and social significance of some natural resources during various historical periods (iron, aluminum, uranium, low-grade ores, rubber, oil) (Rosenberg, 1972), influences of the polluted environment on human's health (Platt, 2000).

Summing up the review of foreign researches, the author draws a conclusion that the formation of such a wide range of private research tasks within one of the directions of ecological history testifies not only to the relevance of the studied issues, but also shows its scientific significance and versatility that open good perspectives for further researches.

Steady interest in environmental issues study, search of ways of their solution was developed in Russian historiography in the second half of the XXth century. Significant growth in quantity and the importance of publications of scientific and popular scientific character, extension of research activity, increase of researchers representing various guidelines (biology, geography, ecology, economy, philosophy, jurisprudence, medicine) became indicators of these positive changes. However, a purposeful approach of historians to human nature 
system was shown "generally only since the beginning of the 80s" (Palekhova, 2000); that caused insufficient study of historical aspects of an environmental problem so far.

Historical researches of the 1980s which were mainly focused on the history of ecological policy of the country allowed to expand considerably the content of the issue, to concentrate attention not on separate natural elements, but on nature as a whole (Alimov, 1982; Gritsenko, 1982). In the 1990s the range of historical works on ecological policy considerably extends, important sources from the funds of central and regional archives are introduced into scientific use, a number of theoretical issues are developed (Sokolov, 1994, 1995; Pushkarenko, 2000). The sources of modern environmental problems which are naturally connected with the previous economic development of the country are studied more objectively in the works of Pidzhakov (1996), Palekhova (1991), Tupikova (1993) and other researchers.

Steady increase of historical and ecological issues promoted the emergence of special historical researches of V. Bragina, Ignatovich, and Saryan (1999), Platonova (1989) in which, along with general regularities of a human, society and nature relationship evolution, there were considered such important aspects of the issue as expansion of geography and environmental management scales, increase of industrial impact on the environment, emergence of complex ecological situations in various regions of the country. Interest provoking material was presented in thematic collections, materials of special conferences that united a wide range of historians investigating various issues concerning the history of society and nature reciprocal influence and interaction.

There can also be singled out some works that study the evolution of economic environmental management Attempts to study this process, that has become urgent due to the exhaustion of many raw stocks of the country, were undertaken by Vasilyeva (1985), Bondareva (1999), Matveeva (1996) and others.

The most important from the positions of methodological approaches updating are pioneer works of Ural scientists Gavrilova (1992), Bakunina (1991), Kuzmina, Orudzhiyev, and Alferova (1997), Tolstikova (1999) and other researchers that explore the history of natural resources opening and operation in eastern regions of the country, ecological consequences of powerful industrial basis establishment, adaptation of a human to the conditions of new development.

Similar innovative researches organically integrated into historical and ecological perspective that is being developed in Russian and foreign historiography; such aspects as the analysis of various aspects of humankind and nature relationship during different historical periods, and realization of important predictive function of historical science make its subject. In this regard scientists' awareness about the necessity to understand the versatility of historical process by obtaining ecological experience gained by humankind, understanding of its place and mission in the world is naturally determined. As one of the components of this task there has been put forward in the research the need to study objectively and completely the development of Russian industry in its integrity with consistently increasing technogenic impact on the environment; the results of this study should be reflected in works on Russian and regional history.

\section{Conclusion}

Thus, the priority guideline of ecological history is a historical research of ecologic-economic contradictions that grew in number dramatically since the first stages of human evolution. Consumer attitude to nature and natural resources that was developed for thousands of years and led to disequilibrium in ecosystems has become the most important reason for crisis of society and nature relationship.

The analysis of Russian and foreign researches on issues of a human and environment interaction, the typical feature of which is its interdisciplinary character, allowed to define that the historical and ecological perspective began to develop abroad since the 1960s, and in Russia only in the 1980-1990s. Special researches of foreign ecological historians that have been characterized in this article, made it possible to designate such perspective for Russian scientific guidelines of studying contradictions in a human nature system as: origins and evolution of industrial pollution, environmental problems of urbanized territories, dynamic of natural resources exhaustion, water resources management history.

In the second half of the XXth century the world economy, and especially industrial production, entered the period of deep transformation of capitalism caused by dynamic changes in the development of productive forces in connection with the third scientific and technical revolution accompanied with the transition that began from the 1970 s to resource- and labor-saving, environmentally friendly, knowledge-intensive productions and technologies. Technological inferiority of the USSR became the reason why the Russian Federation was considered as the country the territory of which is characterized by significant ecological degradation. Heavy industry, oil production, power, chemistry and petro-chemistry which long-term development was constantly 
dictated by industrial interests without due consideration of ecological factors had and continues to render the main impact on a quality condition of natural resources.

A tough ecological situation in industrially developed regions of the country resulted in a sharp disequilibrium between reproduction of natural and ecological potential and its disproportionate consumption, pollution and violation of the main components of environment. For many decades, social and economic development of large industrial centers of the country was in directive dependence on the state strategy in the development of productive forces which was often determined by industrial ministries of all-union significance. The consequence of technocratic approaches on the territory of Middle Volga region is that they have become powerful industrial zones, their technological functioning was the main reason for quality decrease of surrounding environment

\section{References}

Alimov, A. A. (1982). Policy of the CPSS and the Soviet state in the sphere of environmental management (1917-1925). Leningrad.

Bakunin, A. V., \& Lebedev, V. E. (1991). Regional scientific and technical policy: History issues. Sverdlovsk.

Black, B. (1998). Oil Creek as Industrial Apparatus: Re-creating the Industrial Process through the Landscape of Pennsylvania's Oil Boom. Environmental History, 3(2), 210-229. http://dx.doi.org/10.2307/3985380

Bondarev, L. G. (1999). History of environmental management (Historical ecology): Studies guide for students of geographical faculty of higher education institutions. Moscow.

Bragina, S. V., Ignatovich, I. V., \& Saryan, E. D. (1999). Relationship of society and nature: Short historical sketch. Moscow.

Cook, H. F. (1999). Groundwater Development in England. Environment and History, 5(1), 75-96. http://dx.doi.org/10.3197/096734099779568399

Cumbler, J. T. (2000). Conflict, Accommodation, and Compromise: Connecticut's Attempt to Control Industrial Wastes in the Progressive Era. Environmental History, 5(3), 314-335. http://dx.doi.org/10.2307/3985479

Gavrilov, D. V. (1992). Ecological problems of Ural mining region at the end of the XIXth-The beginning of the XXth centuries. In Ural industry in the period of capitalism: Social, economic and ecological problems (pp. 89-121). Yekaterinburg.

Gritsenko, Z. I. (1982). The activity of the Communist party of Ukraine for rational use of natural resources in agriculture (1965-1975). Kharkov.

Gugliotta, A. (2000). Class, Gender, and Coal Smoke: Gender Ideology and Environmental Injustice in Pittsburgh, 1868-1914. Environmental History, 5(2), 165-193. http://dx.doi.org/10.2307/3985634

Hipkins, S., \& Watts, S. F. (1996). Estimates of Air Pollution in York: 1381-1891. Environment and History, 2(3), 337. http://dx.doi.org/10.3197/096734096779522329

Kalimullin, A. M. (2006). Issues of ecological history. History Issues, 10, 160-165.

Kalimullin, A. M. (2014). Stages of Ecological Policy Development in the Industrial Sector of Russia in the Second Half of the XXth Century: Historical Perspective. Life Science Journal, 11(8s), 492-497.

Kuzmin, A. I. Orudzhiyeva, A. G., \& Alferova, E.Y. (1997). Social and demographic consequences of radiation disasters in the Urals. In Historical experience of interaction of a human and environment in the Urals (pp. 130-145). Yekaterinburg.

LeCain, T. (2000). The Limits of 'Eco-Efficiency': Arsenic Pollution and the Cottrell Electrical Precipitator in the U.S. Copper Smelting Industry. Environmental History, 5(3), 336-351. http://dx.doi.org/10.2307/3985480

Matveyeva, S. A. (1996). Culture of environmental management in historical dynamics (pp. 64-66). International conference "Ecological experience of humankind: the past in the present and the future": Scientific abstracts.

McCarthy, T. (2001). The Coming Wonder? Foresight and Early Concerns about the Automobile. Environmental History, 6(1), 46-74. http://dx.doi.org/10.2307/3985231

Meikle, J. L. (1997). Material Doubts: The Consequences of Plastic. Environmental History, 2(3), 278-300. http://dx.doi.org/10.2307/3985351 
Paavola, J. (2002). Water Quality as Property: Industrial Water Pollution and Common Law in the Nineteenth Century United States. Environment and History, 8(3), 295-318. http://dx.doi.org/10.3197/096734002129342684

Palekhova, P. V. (1991). Russian society: History and ecology. Moscow.

Palekhova, P. V. (2000). The State ecological policy and its realization in the Russian Federation in the 1950-1990s Dis....dr. hist. sciences (p. 20). Moscow.

Pidzhakov, A. Y. (1996). Ecological policy of the USSR, the mid of the 60s-The beginning of the 90s (Thesis $\mathrm{PhD}$, Saint Petersburg).

Pisani, D. J. (2000). Beyond the Hundredth Meridian: Nationalizing the History of Water in the United States. Environmental History, 5(4), 466-482. http://dx.doi.org/10.2307/3985582

Platonov, G. V. (1989). Problem of history periodization of society and nature relationship. Problems of interaction of a human and biosphere (pp. 202-208).

Platt, H. L. (2000). Jane Addams and the Ward Boss Revisited: Class, Politics, and Public Health in Chicago, 1890-1930. Environmental History, 5(2), 194-222. http://dx.doi.org/10.2307/3985635

Pushkarenko, A. A. (2000). Nature protection activity in the area of Donskoy's army in the second half of XIXth -The beginning of the XXth centuries (Thesis PhD, Rostov-on-Don).

Quam-Wickham, Ny. (1998). Cities Sacrificed on the Altar of Oil: Popular Opposition to Oil Development in 1920s Los Angeles. Environmental History, 3(2), 189-209. http://dx.doi.org/10.2307/3985379

Rosenberg, N. (1972). Technology and American Economic Growth. New York.

Santiago, M. (1998). Rejecting Progress in Paradise: Huastecs, the Environment, and the Oil Industry in Veracruz, Mexico, 1900-1935. Environmental History, 3(2), 169-188. http://dx.doi.org/10.2307/3985378

Schneider, D. W. (1996). Enclosing the Floodplain: Resource Conflict on the Illinois River, 1880-1920. Environmental History, 1(2), 70-96. http://dx.doi.org/10.2307/3985113

Sokolov, V. V. (1994). Sketches of Russia's ecological policy history. SPb.

Sokolov, V. V. (1995). The history of ecological policy in the Russian Federation (Thesis $\mathrm{PhD}, \mathrm{SPb}$ ).

Stradling, D., \& Thorsheim, P. (1999). The Smoke of Great Cities: British and American Efforts to Control Air Pollution, 1860-1914. Environmental History, 4(1), 6-31. http://dx.doi.org/10.2307/3985326

Te Brake, W. H. (1975). Air Pollution and Fuel Crises in Preindustrial London. Technology and Culture, 16, 337-359. http://dx.doi.org/10.2307/3103030

Tolstikov, V. S. (1999). Social and ecological consequences of the nuclear industry development in the Urals: Historical aspect (Thesis $\mathrm{PhD}$, Chelyabinsk).

Travis, A. S. (1997). Poisoned Groundwater and Contaminated Soil: The Tribulations and Trial of the First Major Manufacturer of Aniline Dyes in Basel. Environmental History, 2(3), 343-365. http://dx.doi.org/10.2307/3985354

Tupikov, A. V. (1993). Ecological policy of the Soviet state in the 70-80s (On the materials of government bodies, party and public organizations of Volga region) (Thesis $\mathrm{PhD}$, Saratov).

Tvedt, T. (2010). Water Systems, Environmental History and the Deconstruction of Nature. Environment and History, 16, 143-166. http://dx.doi.org/10.3197/096734010X12699419057179

Vasilyeva, V. N. (1985). Historical development of environmental management and principles of its rationalization (Thesis $\mathrm{PhD}$, Moscow).

Velayutham, S. (2001). Technological Transformation and Water Conflicts in the Bhavani River Basin of Tamil Nadu, 1930-1970. Environment and History, 289-334. http://dx.doi.org/10.3197/096734001129342496

Walliss, J. (2012). Exhibiting Environmental History: The Challenge of Representing Nation. Environment and History, 18, 423-445. http://dx.doi.org/10.3197/096734012X13400389809418

White, G. F. (2000). Water Science and Technology: Some lessons from 20-th century. Environment, 42(1), 30-38. http://dx.doi.org/10.1080/00139150009604859

Wikan, A. (2012). Towards some general ecological principles. J. Math. Stat., 8, 446-460. 
http://dx.doi.org/10.3844/jmssp.2012.446.460

\section{Copyrights}

Copyright for this article is retained by the author(s), with first publication rights granted to the journal. This is an open-access article distributed under the terms and conditions of the Creative Commons Attribution license (http://creativecommons.org/licenses/by/3.0/). 